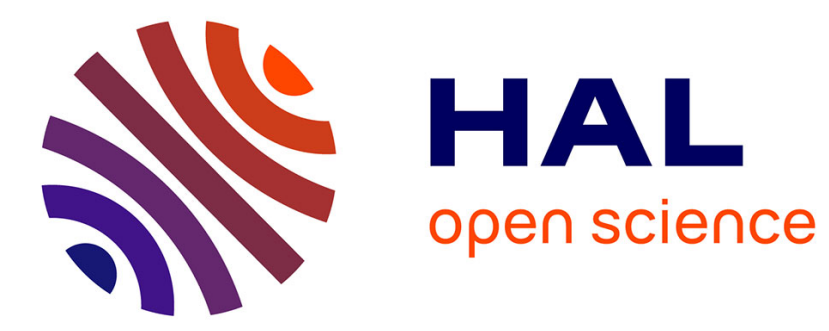

\title{
Livestock waste treatment systems for environnemental quality, food safety, and sustainability
}

\author{
José Martinez, P. Dabert, S. Barrington, C. Burton
}

\section{To cite this version:}

José Martinez, P. Dabert, S. Barrington, C. Burton. Livestock waste treatment systems for environnemental quality, food safety, and sustainability. Bioresource Technology, 2009, 100 (22), p. 5527 p. 5536. 10.1016/j.biortech.2009.02.038 . hal-00504207

\section{HAL Id: hal-00504207 https://hal.science/hal-00504207}

Submitted on $20 \mathrm{Jul} 2010$

HAL is a multi-disciplinary open access archive for the deposit and dissemination of scientific research documents, whether they are published or not. The documents may come from teaching and research institutions in France or abroad, or from public or private research centers.
L'archive ouverte pluridisciplinaire HAL, est destinée au dépôt et à la diffusion de documents scientifiques de niveau recherche, publiés ou non, émanant des établissements d'enseignement et de recherche français ou étrangers, des laboratoires publics ou privés. 
Author-produced version of the article published in Bioresource Technology, 2009, 100, 22. 5527-5536.

Original publication available at www.sciencedirect.com - doi:10.1016/j.biortech.2009.02.038

\title{
Livestock waste treatment systems
}

\section{for environmental quality, food safety, and sustainability.}

\author{
José Martinez ${ }^{1}$, Patrick Dabert ${ }^{1}$, Suzelle Barrington ${ }^{2}$, Colin Burton ${ }^{1}$ \\ ${ }^{1}$ Cemagref, Environmental and Biological Treatment of Wastes Research Unit \\ 17 Avenue de Cucillé, CS 64427, 35044 Rennes, Cedex, France \\ E-mail : jose.martinez@,cemagref.fr, tel +33223482130, fax +332234821 15, corresponding author \\ ${ }^{2}$ Department of Bioresource Engineering, Macdonald Campus of McGill University, 21111 Lakeshore, \\ Ste Anne de Bellevue, Quebec, Canada H9X 3V9
}

\begin{abstract}
The intensification of livestock operations has benefited production efficiency but has introduced major environmental issues, becoming a concern in both developed and developing countries. The aim of this paper is primarily to address the impact of the livestock sector on environmental pollution (ammonia, greenhouse gases and pathogens), evaluate the related health risks and, subsequently, assess the potential role of waste treatment systems in attenuating these environmental and health issues. This paper is a collection of data pertaining to world trends in livestock production, since the mid 1990's and intensive livestock farming practices along with their impact on: water pollution by nitrates and through eutrophication; air pollution, particularly ammonia and greenhouse gases emissions, and soil pollution because of nutrient accumulation. Finally, this paper examines some of the benefits of treating livestock manures, issues related to the adoption of treatment systems by livestock operations and current as well as past technological developments.
\end{abstract}

Key words : livestock wastes, environmental risk, treatment.

\section{Introduction}

As an integral part of the traditional farming system, livestock was crucial in contributing to the sustainability of agricultural systems by: (i) utilizing crop residues and other feeds which were not used 
by humans and by converting them into milk and meat; (ii) providing a soil amendment (manure) which recycles about $70 \%$ of the feed minerals which are not digested and otherwise would be lost, and; (iii) for the poorest regions of the world, providing traction for cultivation, supply for energy production or home construction (dried cowpat). However, the price of goods produce in farm operations has not increased since the late 1960 's, while all other costs have increased by more than 10 times. This price trend has forced the mixed farming system into intensive livestock operations, and in turn, greatly modified the fine and well balanced cycle of using manure nutrients to replenish the soil with minerals. The animals are fed directly by cereals feed from which a high proportion (not assimilated by animals) is finally released into the environment with or without prior treatment. It results in global losses of nutrients at several levels: concurrence with the use of cereals in human food, low efficiency of cereals uptake by animal, cost of manure treatment before spreading when it is necessary and negative impact on the environment in areas of animal concentration. Modern intensive livestock operations exert considerable environmental impacts, a subject of increasing concern for developed countries but also for developing countries with a lack of policy and strict rules requiring environmental protection.

The future of livestock farming is therefore at the heart of a serious debate concerned with the critical issue of the global food crisis. Three main challenges are faced :

1. Policy perspectives and risk prospects associated with the intensification of livestock production, particularly within the fast growing economy of developing countries;

2. Environmental issues linked with the over-use of natural resources and the subsequent depletion of their ability to regenerate; these environmental issues pertain to air pollution such as greenhouse gases emissions, soil pollution through nutrients build-up and saturation and water quality;

3. Technological changes inducing the "accelerated" implementation of well-known treatment systems in developed countries and the adaptation or technological transfer of these solutions to developing countries.

The Green Revolution which emerged after World War II was driven by supply, and inputs, such as fertilisers, pesticides and irrigation water, and better genetic potential which brought tremendous improvements in production efficiency. At the same time, the low prices for food produce at the farm assured an affordable food supply accessible to most, particularly in developed countries (Hodges, 2005). 
Along with this trend of providing low cost and plentiful food supply, the end of the twenty century was characterised by the so-called "livestock revolution". This revolution was mostly driven by a strong demand for food from animal origin, still at a low farm cost. It resulte a change in diet for billions of people, as well as an important population growth (Gerber et al., 2005, Gerber \& Steinfeld, 2006). The pressure to maintain low prices for produce at the farm widened the gap between rural and urban economies, leading to greater urbanization and income growth in developing countries (Adhikari et al., 2006). In speaking of food, the entire human life is impacted, as "food is life" (Hodges, 2005).

Nevertheless, the production of organic residues is inherent to the livestock farming activity, and among these residues, animal manures are by far the more important stream.

In Europe, the move from mixed arable-livestock farming to greater specialization has had a major adverse environmental effect. The environmental effects of different livestock manure systems have been the subject of scrutiny and a number of reviews and reports were produced (Nicholson et al., 2002; Voermans et al. 1994; Martinez \& Le Bozec, 2000; Hooda et al., 2000; Leinweber et al., 1997). Among these, the poor management of livestock effluents has directly impacted the nitrogen load in soil and the subsequent transfer to surface and groundwater resources. The European community first introduced nitrate regulations in 1991 to address this issue and more recently the EU-27 introduced the water framework regulation aimed at improving water quality. In addition and for the last 30 years, the gaseous emissions of ammonia nitrogen is a major topic of concern in Europe, first because it represents a loss of valuable nutrient and second because this gas exerts negative effects such as eutrophication and acid rains. The European community is presently applying a regulation pertaining to ceilings in ammonia emissions.

Unlike the current approach which tends to install manure treatment processes as a constraint at the end of a chain of livestock production, a most holistic, environmentally safer and reasonable choice would be to define the types of livestock and manure management to be developed in light of the remediation capacities of their environment. In other words, think about manure management before or at least at the same time as the animal production mode itself. Thus, according to the needs of the land, the treatment could sometimes be unnecessary, sometimes necessary or optional, but always seen as an alternative to further transform manure in co-products or energy. There exist solutions which, at the moment, are mainly focuses on the elimination of organic matter and nitrogen. Other solutions to the excess manure 
problem need to be created, as for energy production, recycling of phosphorus or greenhouse gases emissions reduction.

Treatment technologies can play a role in the management of livestock manure by providing a more flexible approach to land spreading and by resolving specific problems such as malodours or ammonia emissions. Such treatments are based on biological and physical processes, with the possible use of chemical additives. The technologies already used by large farms are separation and composting, anaerobic digestion and aeration. The challenge for many countries is how to implement such technologies both at a wider scale and economically. In countries outside Europe and North America, the adaptation and development of specific treatment systems must deal with regional constraints and cultural peculiarities. For examples, in Japan and South-East Asia, cultural concerns prescribe the use of manure to fertilize soils and climatic conditions have a major impact on the selection of the treatment, the dilution of the waste and the potential for runoff (Burton \& Martinez, 2008).

The objective of this paper is therefore to assess and review the potential role of treatment systems in dealing with surging environmental pollution issues. This paper examines the potential use of manure biomass within a renewable context, and in terms of reducing greenhouse gases emissions.

\section{The future of animal production}

\subsection{Global production, general trends and perspectives}

The current world population is unevenly distributed economically and socially. Five billion people live in the "developing world" whereas the "developed world", sometimes called "The West", represents less than one billion people.

As the economy of these countries improves, their demand for animal products is likely to increase, along with a greater disparity between rural and urban economies resulting in a greater urban population growth. The disparity between rural and urban economies results from the fact that the price of farm products have not increased since the early 1970's, while all other costs have. As a result of a greater income, a diet richer in meat, milk and eggs can improve human nutrition. In contrast to the developed world where many people eat too much animal products, most people in developing countries eat too 
2.2. Major nutrient flows

The importance of livestock production for every person on the planet is illustrated by the increasing demand for meat, eggs and dairy products for at least the developing countries (Faye \& Alary, 2001). Also, livestock production has an impact on the global flow of nutrients, particularly for $\mathrm{N}$, an important nutrient for agriculture and the environment. Table 2 illustrates the respective needs for $\mathrm{N}$ between the human population and the global livestock farm system. The global $\mathrm{N}$ intake by animals is estimated as 110 million tons/yr while the global $\mathrm{N}$ excretion by animals is estimated at 100 million tons, implying a $10 \%$ efficiency in $\mathrm{N}$ use (Bouwman \& Booij, 1998). This illustrates the strategic importance of optimizing the recycling of manures and to use them as a resource and an organic fertilizer. The global swine population produces roughly 1.7 billion tons/yr of liquid manure which can, at an application rate of 40 tons/ha, fertilize 45 million ha of land annually (Choudhary et al., 1996). 
In a paper revisiting the agronomic benefits of manure, Schröder (2005) described agriculture as a chain of activities transferring nutrients in a cyclic way: (1) from the soil; (2) via the crop; (3) via the animals and humans, and; (4) via manure back to the soil again. Each step is characterized by an efficiency value or a ratio of outputs and inputs, which gives an indication of the transfer efficiency for $\mathrm{N}$ (Table 3 ), reinforcing the fact that the introduction of mineral fertilizers has significantly disturbed the balance between crop and animal production. The question is therefore how to restore such integrity without going back to historical times and ancient practices, but within a modern and sustainable agricultural system.

This problem is even more crucial for phosphorus. While nitrogen can be artificially synthesized from natural gas, phosphorus is a non-renewable resource extracted from soil, which is expected to be depleted. Since mineral fertilisers and animal feeds account for approximately $80 \%$ and $5 \%$ of phosphates used worldwide, it is clear that depletion of phosphorus production will impact animal production and manure recycling within the next decades.

\section{Environmental impact of Livestock Waste}

\subsection{Soil pollution}

Animal manures were regarded historically as beneficial soil amendments rich in nutrients and organic matter that also sustain the soil physical properties such as structure and moisture retention. Farmers have traditionally applied these organic fertilisers for the long term benefit of their soils. Manure helps stabilization of soil aggregates preventing erosion, it improves soil structure promoting moisture retention and it even may correct drainage problems in wet areas.

Repeated soil over-applications of manure, above crop requirements, lead to the accumulation of not only macro nutrients such as $\mathrm{N}, \mathrm{P}$ and $\mathrm{K}$, but also heavy metals particularly $\mathrm{Cu}$ and $\mathrm{Zn}$, impacting animal health through grazing and crop feeding (Lopez Alonso et al., 2000). The main consequence of nutrient overloaded soils is related to the interaction between soils and its water and air fractions. Water pollution occurs mainly through the leaching of nitrates applied in excess of plant uptake, while air pollution is the consequence of complex processes including nitrification/denitrification and also the breakdown and transformation of organic matter in soils (Figure 2). Soils plays therefore a major role in the retention, 
transformation and release of gaseous or soluble compounds. In some cases, like for methane, soils can act as sink, through oxidation processes.

\subsection{Water pollution}

Water pollution by animal production is often caused by the leaching and runoff of minerals from the soil or by direct disposal of wastes into watercourses. Animal manure nutrients in excess of crop uptake, accumulate and even saturate soils. At saturation, nutrients are lost to either surface or ground waters. Nitrogen and phosphorus are the two nutrients of special agricultural importance with the greatest potential to create water pollution. Although not an issue presently, potassium $(\mathrm{K})$ will be another problem in the near future as the application of manures based on the plant uptake of $\mathrm{P}$ generally leads to the surplus application of this mineral (Béline et al., 2003). Both $\mathrm{N}$ and $\mathrm{P}$ surplus can pollute surface waters through runoff while limited amounts are immobilised by the soil organic matter. Free ammonia, rather than the ammonium salt, has a greater impact on water systems because of its toxicity to many fish species. For instance, Salmon, an ammonia sensitive fish, is affected by $5 \mathrm{mg} / \mathrm{L}$ of ammonia.

While documenting the water quality concerns in livestock areas, Hooda et al. (2000) specifically illustrated the problem and concluded that there is a general uncoupling of nutrient cycles, and problems related to nutrient loss are either short-term direct losses or long-term, related to accumulated nutrient surpluses.

\subsection{Air pollution}

Animal production has been identified as a major contributor to atmospheric pollution (Pain, 1999). The air in livestock housing contains over a hundred gaseous compounds released into the atmosphere by the ventilation system. Of these gases, odorous substances and especially ammonia have been the main concerns from an environmental perspective (Hartung and Phillips, 1994). The largest proportion of the gases arising from animal husbandry is produced from freshly deposited or stored faeces and urine, through microbial activity.

\subsubsection{Emissions of ammonia}



which 43 million tons $\mathrm{NH}_{3}-\mathrm{N} / \mathrm{yr}(80 \%)$ stems from anthropogenic sources. The major anthropogenic sources include excreta from domestic animals (50\%) and use of synthetic $\mathrm{N}$ fertilisers (25\%) (Olivier et al., 1998). In 1990, anthropogenic ammonia emissions to the atmosphere in Western Europe were estimated at 2.8 - 5.2 million tons $\mathrm{NH}_{3}-\mathrm{N} / \mathrm{yr}$. Manure from farm animals was the principal source (ECETOC, 1994) and their emissions were damaging the environment through soil acidification and eutrophication. In addition, these emissions constitute an important loss of valuable $\mathrm{N}$ fertiliser. The loss of ammonia to the atmosphere occurs from animal housing, manure storage facilities, and from the application of manure to land. Approximately $50 \%$ of the ammonia emissions from swine production originate from the shelter and the slurry storage, while the other $50 \%$ is emitted following land application. The most important factors influencing ammonia emissions are the concentration of ammonia nitrogen in the slurry, the emitting surface, the $\mathrm{pH}$ of the slurry, the air velocity over the slurry and the slurry temperature (Van der Peet-Schwering et al., 1999). In animal house, $\mathrm{NH}_{3}$ is a health risk to animal and man, because long term exposure to $\mathrm{NH}_{3}$ combined with dust can cause severe lung diseases (Seedorf et Hartung, 1999). Furthermore, high concentration of $\mathrm{NH}_{3}$ may reduce animal performance.

In Europe and over the past decade, ammonia emissions has been a concern because of high deposition rates on land and over water surface, causing long-term damage to sensitive natural and semi-natural ecosystems. Transported over long distances in the atmosphere, ammonia is both a national and international problem. EU Member States are signatories of international agreements to limit emissions. The UNECE "Protocol to Abate Acidification, Eutrophication and Ground-level Ozone" (also known as Gothenburg Protocol) was signed in 1999 under the 1979 Geneva "Convention on Long-range Transboundary Air Pollution” and entered into force on 17 May 2005 (Mallard, 2006). The main signatories are the European Community, the European countries, the Unites States of America and the Russian Federation, this last one having not ratified the protocol yet. The protocol fixes national annual emissions targets for different gases: $\mathrm{SO}_{2}, \mathrm{NO}_{\mathrm{X}}, \mathrm{NH}_{3}$ and volatile organic components (VOC), to be reached by 2010 .

On this basis, the 2001 NEC directive (directive 2001/81/EC of the European Parliament and of the Council) fixes national emissions ceilings for the same different gases, to be reached for the same year and, for ammonia, at the same level as the Gothenburg Protocol. The NEC directive is currently in the 
process of implementation. Member States had to build national programmes (by October 2002), to show how they were going to meet the national emission ceilings by 2010 (this programmes were updated and revised in 2006).

\subsubsection{Methane and nitrous oxide emissions and climatic change}

The current predictions of climatic disruption caused by human activities include one scenario where there is a possible temperature increase of up to $4^{\circ} \mathrm{C}$ within the next 40 to $75 \mathrm{yr}$. With respect to agriculture, such a climatic change might result in the drying up of currently fertile large land surfaces. Cold regions such as the tundra of the northern hemisphere will not necessarily become suitable for crop production. More specifically, there is no reason to assume that agriculture will adapt quickly enough to any climatic change resulting from the global "warming" trend.

Methane and nitrous oxide are major greenhouse gases implicated in the global warming phenomenon. They are also involved in the photochemical reactions in the troposphere that determine concentrations of ozone and hydroxyl radicals. Hydroxyl radicals are termed the 'detergents of the atmosphere' because they are responsible for the removal of almost all gases that are produced by natural processes and human activities.

The Intergovernmental Panel on Climate Change (IPCC) calculated that $1 \mathrm{~kg}^{\text {of } \mathrm{CH}_{4}}$ has 63 times the warming effect of $1 \mathrm{~kg}$ of $\mathrm{CO}_{2}$, over a period of 20 years following the gas release (calculated over one hundred years, the warming effect of methane is 21 to 23 times the warming effect of $\mathrm{CO}_{2}$ ). The average atmospheric $\mathrm{CH}_{4}$ concentration is currently $1.7 \mathrm{ppmv}$ (parts per million by volume) or approximately, depending on temperature and pressure, 1.2 micrograms $/ \mathrm{m}^{3}$ of air. The concentration started to increase from a baseline value of about 0.8 ppmv in pre-industrial times 200-300 years ago and is currently increasing at a rate of about $1 \% / y$. The increased abundance of $\mathrm{CH}_{4}$ will have important impacts on global climate changes, and on the tropospheric (ground-based) and stratospheric ozone layers. Methane is estimated to contribute about $20 \%$ of the expected global warming trend, second only to $\mathrm{CO}_{2}$. Nitrous oxide has a global warming effect ten times that of $\mathrm{CH}_{4}$ and hence its lower concentration in the stratosphere still equates that of $\mathrm{CH}_{4}$. For both gases, the largest single source of anthropogenic emission is agriculture (Duxbury, 1994) (Table 4). In case of ruminant production, the majority of methane emission is from enteric activity that cannot be reduced in a short time period, or may not be reduced at 
all. On the opposite, in case of pig production, $89 \%$ of methane emissions are due to manure management storage and could be reduced by changing manure management practices or biogas collection (Table 5). A recent FAO report (2006) estimates that 35\% of global greenhouse-gas emissions deriving from agriculture and land use comes from livestock production. This sector accounts for about $18 \%$ of global greenhouse-gas emissions, consisting in around $9 \%$ of global emissions of carbon dioxide, plus $35-40 \%$ of methane emissions and $65 \%$ of nitrous oxide.

\subsubsection{Dust and other particles}

Dust has not been reported as an important environmental issue in the surroundings of farms. Inside the animal house however, it is known to be a contaminant that can affect both the respiration of the animals and the farmer (Copeland, 2006; Anderson et al., 2003).

The highest concentration of airborne dust, bacteria, fungi and endotoxins can be found within poultry shelters but high values also occur in swine shelters. Table 6 gives an overview of the different bioaerosols components found in livestock shelters. Exposures to bio-aerosols in animal shelteres are associated with a wide range of adverse health effects, including infectious and non-infectious diseases. Endotoxins are particularly harmful since they can induce allergic reactions of the respiratory system that can become chronic.

\subsection{Disease risks and health issues}

Livestock waste may contain various pathogenic microorganisms (bacteria, viruses or parasites) that can present a sanitary risk during their subsequent spreading on agricultural land. Whilst some pathogens are obligate parasites and are of limited concern, others can survive in the environment for long period (as viable cells or more often as cyst or spore). Pathogens survival and movement through soil depends upon many factors like soil type, water content and $\mathrm{pH}$; microorganisms surface properties and motility and environmental factors like temperature, plants and micro-and mesofaunal activity (Abu-Ashour et al., 1994).

Hygiene concerns resulted from a series of food scares resulting from the microbiological contamination of agricultural food products such as Salmonella, E-coli, campylobacter and also BSE (Bovine Spongiform Encephalopathy). Examples of notable outbreaks of diseases affecting even livestock are the 
foot and mouth disease, the classical swine fever and more recently, the avian influenza which exemplifies a possible zoonotic disease further endangering the general public. Manure disposal will certainly be an issue during any of these outbreaks. De-contamination will be conducted either by the addition of proven disinfectants or, for very large quantities, extended storage for the long term demise of the specific pathogen.

Few incidences of water contamination by zoonoses were reported but each tends to be a very serious event with human fatalities (Guan and Holley, 2003). Accordingly, additional restrictions were imposed on where and how manures may be land spread but no treatment was mandatory when aeration, especially at temperatures over $50{ }^{\circ} \mathrm{C}$, anaerobic digestion, the use of disinfectants and prolonged isolated storage can be very effective (Burton and Turner, 2003) but without total elimination. Thermal treatments constitute a more rigorous and reliable approach (Turner and Burton, 1997) although less costly than originally expected, but the use of such technology is still limited to specific areas of high risks. During non epidemic periods, drastic treatment is not required for manure that is simply stored for 4 to 6 months before spreading. This storage allows the number of pathogens possibly present in manure to decrease but not to totally disappear. In the case of pig manure, the antimicrobial effectiveness of 5 biological treatments of manure has been evaluated by the enumeration of 3 treatment indicators (enterococci, Escherichia coli and Clostridium perfringens) and the detection of two pathogenic bacteria (Salmonella and Listeria monocytogenes) (Pourcher et al, 2007). The studied treatments consisted either of a simple storage of the raw manure, or of more complex treatments designed for the removal of nitrogen and phosphorus (biological treatment with or without physical separation of manure). The results underlined the existence of a potential risk of spreading Salmonella which were detected in $60 \%$ of the 17 raw manures and in $20 \%$ of the 10 treated manures analysed. The $\mathrm{N}$ removal treatment resulted in a decrease in $E$ coli and enterococci concentrations, but was not however sufficient to completely eliminate the pathogenic bacteria and it had no effect on the spores of $C$ perfringens. Indeed only the composted manure separated solid and the treated manure separated liquid from the pond appeared free of (or undetected) pathogens.

As a consequence, spreading of raw or even stored untreated manure presents a danger even if the actual risk of contamination has not been evaluated. It has been observed that spreading resulted in a transient increase in number of pathogenic microorganisms in soil (Gessel et al., 2004). The health risk increases 

intended to be cooked are grown (Nicholson et al., 2005). Recently, the European regulation has been strengthened concerning the hygienic quality of recycled animal by-products like composted raw manure separated solids (regulation $\mathrm{n}^{\circ} 1774 / 2002$ ). It requires animal by-products to contain less than 5 x $10^{3} \mathrm{E}$. coli or enterococci per $\mathrm{g}$ of product and the absence of Salmonella in $25 \mathrm{~g}$ of product.

From a disease perspective, the biggest impact of manure management is likely that of food quality, rather than from governments regulations. Farm produce quality is impacted by the method of applying the manure on crops and the most vulnerable crops are leaf vegetables eaten raw. Because such application is forbidden by law, manure land application as part of a farm cycle may become increasingly difficult and the consequence may further encourage the treatment of manure at the farm.

\section{Treatment systems for livestock wastes: assessment of their future role}

\subsection{Technological options}

Livestock operations can benefits from the adoption of better management methods that simultaneously improve production efficiency. Inevitably, an efficient waste collection and storage system is required before land disposal. Many European and North American farms have already adopted equipment or techniques simplifying this operation such as mixers and separators which reduce blockage problems and facilitate transportation. In some cases, these measures can minimize environmental impacts, because they result in a more uniform land application of manure nutrients. In a few cases, financial rewards such as a premium price for electricity generated from the anaerobic digestion of organic wastes has encouraged the adoption of treatment technology. Otherwise, the benefit gained from manure treatment technologies generally do not cover their investment cost and operation complexity, resulting in most farms in Europe and North America responding only under the pressure of environmental legislation. As opposed to direct land application, the treatment of manure implies processing technology changing its physical or chemical characteristics. This may be brought about by physical, chemical, mechanical or biological processes or a combination of these. A wide range of equipment and systems are potentially available in Europe and North America to treat manures (Burton \& Turner, 2003) but few were adopted on a large scale because of : 
- $\quad$ heavy investment and operating costs without an equivalent return;

- $\quad$ their complexity and impracticality for the livestock operator;

- $\quad$ poor adaption for the livestock farm;

- further environmental problems arising from the process, such as odours.

Further development may yet reduce these constraints, but for the present, Europe and North America livestock operation have adopted the following practical options for manure treatment :

- Composting systems or related technologies producing a useful solid product;

- Biological systems for liquids that effectively breakdown some of the organic load;

- Separation systems removing solids for the clarification and/or concentration of manure nutrients.

Storage, mixing and application systems by themselves do not constitute a manure treatment but they are crucial in minimizing the environmental impact. Although certain chemicals such as lime or flocculants are used to precipitate some manure components, they use alone rarely constitutes an adequate or sustainable treatment to minimize the manure problems.

In situations where manure nutrients exceed crop uptake, surplus nutrients must be transported outside the region to prevent an undesirable environmental impact. There are three broad options partly in use in Europe and North America :

- Transport of unmodified manure to other regions,

- Removal of unwanted components;

- $\quad$ Separation and processing of surplus components into a useful product.

Road haulage and, for shorter distances, pipeline transfer, has been used in parts of Europe and North America, especially the Netherlands, as a direct method to re-distribute manure surpluses. To some extent, this redistribution of manure nutrients is a step back towards the former times when farms were smaller and more evenly distributed. However, the environmental impact of the extra transport cost and fuel consumption must be included in any assessment. Pipeline transport is easier once the initial investment has been made but pre-treatment to remove some suspended matter is necessary and the engineering problems increase with distance.

Another option is the removal of manure components such as $\mathrm{N}$ through aerobic/anoxic processes, and the organic load, through aerobic and anaerobic treatment. Nitrogen removal is achieved via the process 

surpluses (Béline et al.2004). Any biological process can be expected to breakdown organic matter. With aeration, organic matter is oxidized to produce carbon dioxide and water, while with anaerobic digestion acetic acid is produced and then used by methanogens to produce methane.

Manure components which cannot be eliminated, such as phosphorous and heavy metals, can only be removed by separation, concentration and exportation. This may be the desired process for all excess nutrients including nitrogen and organic matter when there is a recognised value. Separation is achieved through screening, centrifugation and sedimentation. Screening works best with cattle manure where some 30 to $40 \%$ of the solids can be separated from liquids by screens with perforations of $1.5 \mathrm{~mm}$ and the resulting solids are ideal for composting. Centrifugation is better adapted to swine and poultry slurries where particles are generally finer than $0.7 \mathrm{~mm}$, because the fine texture of feeds that improves digestion (Barrington, 2002). Again, the final product has a solids content of $30 \%$, which is ideal for composting. The use of flocculants along with centrifugation can further improve the separation of swine and poultry manure solids and nutrients. Sedimentation by gravity using large shallow vessels produces sludge with a dry matter concentration of only 5 to $10 \%$ (Martinez et al., 1995).

Solid products whether from sludges, or solid litter, can be blended or used as they are, to be composted and to produce a useful organic product that is sometimes saleable. The compost process itself adds nothing to the mix but rather produces a stable, aesthetically acceptable and consistent soil amendment which reduces the demand for natural peat, a non renewable resource. Composting reduces the volume of the original material by over $50 \%$ (Barrington, 2002) and thus, lowers transportation costs of surplus manure nutrients. Nevertheless, composting is not a free treatment, costing at least 100 Euros or $\$ 150$ Can. per ton of soil amendment produced, when many soil conditioners are sold on the market for 25 Euro or $\$ 40$ Can (Barrington, 2002). The addition of some mineral fertilizers to the compost material to balance its nutrient content for specific crops may be an interesting alternative and a method of adding value to cover the composting cost. Further research is needed to evaluate the benefits of adding organic matter to agricultural soils, as the value of organic soil amendments is often based on nutrient content. Although of limited impact on the natural environment, offensive odours are regularly associated with intensive livestock operations and constitute a nuisance which is no longer accepted by rural residents. In 
North America, livestock operators are regularly fined because of odour nuisance. Abatement measures include spreading restrictions associated with wind direction and time of the week or year, use of injection systems and covering manure storage facilities. The only two methods which can reduce manure odours during land spreading are aeration or the oxidation process destroying the organic compounds responsible for odour (Burton et al, 1998), and anaerobic digestion. The use of odour controlling additives remains controversial with limited published work actually demonstrating that they work (Figure 3). Nonetheless, the convenience of applying relatively small quantities of proprietary products to liquid manure makes them popular irrespective of their effectiveness. Along with odour control, aeration can further reduce emissions of methane produced otherwise by anaerobic microbes active at the bottom of the storage (Figure 4). Anaerobic digestion can also reduce offensive odour through the degradation of odorous organic compounds. The methane produced must at least be flared and preferably be used for its energy content.

The aeration of manure is an expensive process requiring a considerable amount of energy and this parameter must be considered when assessing the over-all feasibility, benefits and environmental impact of the technology. In North America, livestock producers have limited both of these impacts by aerating manures in the storage tank, for one to two days, just before land spreading. This aeration is done during a rainy day or at night, when offensive odours are not a nuisance (Barrington, 2007a). The anaerobic treatment of manures is a process requiring less energy than aerobic treatment. Although the process is well adapted to tropical regions, a specialist is required to operate conventional anaerobic digesters on livestock operations located in regions with a temperature climate where temperature fluctuations increase the complexity of managing the system. Barrington (2007b) is working on developing an instorage psychrophilic anaerobic digestion system at no cost besides that of the tank cover, and due to its psychrophilic regime requires no special supervision. This system can also help to reduce ammonia emissions from manure during storage.

To conclude on technological options and treatment systems, there is room for a key role in the future for such systems to be more widely implemented, firstly for the control of gaseous emissions (ammonia but also greenhouse gases) and secondly for the control of environmental sanitation. In regard to controlling or reducing greenhouse gases, there is not at the present a consensus but rather "contradictory" results. For instance Melse and Verdoes (2005) through an evaluation of four Farm-scale 
nitrification/denitrification system (up to $48 \mathrm{~kg}$ [carbon dioxide equivalents] $\mathrm{t}^{-1}$ [manure] compared to 12 $17 \mathrm{~kg}$ [carbon dioxide equivalent] $\mathrm{t}^{-1}$ manure for the other three systems (Figure 5). But mostly the GhGs losses occurred through nitrous oxide emissions, which indicates a lack of control of the system by the manufacturer. In particular, the use of continuous aeration (versus intermittent) induces considerably large nitrous oxide losses (Béline et al., 1999). On the opposite, a long-term and repeated campaign of measurements (and based on comparing various farm treatment plants) conducted by Loyon et al. (2007) demonstrated that the conventional management of the raw slurry compare to three other treatment options emitted more GhG as well as ammonia (Table 7).

This illustrates once again the need to clarify the objective of the treatment systems before evaluating its "performances" per se, but also the need to implement reliable systems based on "sound" science.

\subsection{Adaptation of natural environments: soil filter systems, constructed wetlands}

Land treatment is based on the physical, chemical and microbiological interactions between the components and the micro-organism of both the soil and the waste. As manure moves through the soil profile, a high degree of purification can occur so long as the degradation and plant uptake capacity is not exceeded (Hawkins et al. 1995). Such a soil filter was introduced by Szögi et al. (1997) to treat the effluent of an anaerobic lagoon treating swine manure. The media, consisted of marl gravel, could remove $54 \%$ of chemical oxygen demand (COD) and $50 \%$ of total suspended solids (TSS). Removal efficiencies for total phosphorus (TP) ranged from $37 \%$ to $52 \%$ while for total nitrogen (TN), up to $24 \%$ was converted to nitrite and nitrate-N, which was denitrified through constructed wetlands. Such higher TP removal efficiencies were likely to require a filter medium change once saturation was reached. Boiran et al. (1996) removed nitrogen from pig slurry using a forced nitrification step within gravel columns. Nitrogen removal of $4 \%$ to $38 \%$ and ammonium-N oxidation into nitrite and nitrate of 64 to $98 \%$ was achieved, depending on the gravel used in the column, whether calcareous or siliceous in nature. A four-stage soil filtering system was investigated by Kuli et al. (1996) in Hungary for the treatment of highly diluted pig slurries with 0.4 to $0.6 \%$ TS. The simple low-cost system is operated from a straw pre-filter followed by a beds of wood shavings, gravel and sandy soil. The system was able 
to take loads of 2.5-5.0 $\mathrm{m}^{3} /$ day and its overall COD and BOD removal efficiencies were 43-76 and 46-88 $\%$ respectively, while $58-99 \%$ of the TSS were removed.

A soil treatment process called a barriered landscape wastewater renovation system (BLWRS) was developed in the USA and consists of a mound of soil over an impermeable barrier and a drainage system. Thus, an aerobic zone was created in the top portion while an anaerobic zone was created in the bottom portion of the BLWRS (Ritter and Eastburn, 1978). Evaluated for two years for the treatment of liquid dairy wastes, the system was capable of removing 90,90 and $99 \%$ of the COD, $\mathrm{N}$ and $\mathrm{P}$, respectively. Again, the filter medium likely required replacing once saturated with $\mathrm{P}$.

In France, the soil filter system, Solepur, was highly successful at removing organic matter and nitrogen (N) from pig slurry during its first five years of operation (Martinez, 1997). The system consisted of three operations: application of large volumes of pig slurry to a managed field; collection and treatment of the nitrate-rich leachate; and irrigation of the treated water over other fields. This study measured the environmental implications of applying excessive volumes of slurry to cropped land and also improved knowledge pertaining to $\mathrm{N}$ cycle within the soil profile.

As regards the treatment of livestock effluents and manures, whatever the options considered either being so-called "technological options" (based on energy, concrete, steel, chemicals e.g. fossil fuel intensive) or "natural options" (based on sun, wind, land, seeds e.g. land intensive) there is clearly no better solution, but rather a range of options which needs to be adapted and implemented according to the local situation and context (social, economical, regulatoty).

\section{Conclusions}

Looking towards the future, we could try to imagine what livestock production and waste management should be and what it may become :

1. Livestock production should have a better integration within other agricultural and agri-food activities to have a better use of both its inputs and its outputs. For its inputs, the necessary increase in animal 

of the "average daily gain". Moreover, the human and economical pressure on cereals will compete more and more with livestock production. We can expect that in the future, the cereals used for animal feeding will be slowly replaced by co- or by-products from agri-food activities, allowing a reduction of the cost of animal feeding and the development of recycling systems of so far unused products.

2. For the outputs, it is also clear that there is a need to imagine new waste management methods that would protect the environment and allow manure management to switch back to a recycling view of manure handling. Within these new techniques, the early separation of liquids from solids in livestock houses may be of particular interest since it reduces gaseous emissions in the buildings and it generates liquid and solids that can be processed separately.

3. Techniques allowing nutrient recycling from wastes, especially phosphorus, should also be developed as well as any techniques allowing an economical and environmental friendly benefit like a better agronomical use of manure or biogas production from manure.

4. The ideal situation would be to work at the same time on both the inputs and the outputs of livestock production and on its integration in its "regional" or geographical aspects. However, to reach such a goal, we need to consider all treatment aspects not only the constraints whatever they are (environmental, sanitary etc) but also the overall consequences integrating economical parameters like cost of livestock buildings, evolution and depletion of fuel energy, phosphorus and may be cheap cereals.

5. We also need to integrate possible stronger policies on environmental protection such as the necessity to include new "emerging" pollutant like antibiotics, endocrine disrupters, antibio-resistant pathogens, etc.

6. The development of such new systems will require the development of new measuring devices and global methods to assess the viability of production chain and food supply. These systems are currently in progress through the Lyfe Cycle Assesment methods. 


\section{Acknowledgement}

The authors would like to acknowledge the USDA-ARS Florence team (Dr. Matias Vanotti, Dr. Ariel Szogi and Dr. Patrick Hunt) for organizing this OECD workshop. 
Abu-Ashour, J., Joy, D.M., Lee, H., Whiteley, H.R., Zelin, S. 1994. Transport of microorganisms through soil. Water, Air and Soil Pollution, 75, 141-158.

Adhikari, B., Barrington, S., Martinez, J. 2006. Predicted growth of world urban food waste and methane production. Waste Management and Research. 24, 421-433.

Anderson, N., Strader, R., Davidson, C. 2003. Airborne reduced nitrogen: ammonia emissions from agriculture and other sources. Environment International 29, 2777-286.

Barrington, S. 2007a. Evaluation de la performance de l'aération temporaire de lisiers à l'entreposage pour réduire les odeurs à l'épandage. Journée d'information sur les odeurs. Fédération de l'UPA de Lanaudière, Joliette, Québec.

Barrington, S. 2007b. La production de méthane avec couverture sur fosse à lisier. Journée sur la méthanisation et les gaz à effet de serre. CRAAQ, MAPAQ, Québec, Canada.

Barrington, S.F. 2002. Reducing odours and manure surplus nutrients at the Macdonald farm of McGill University. CSAE Annual Technical Meeting, Saskatoon, Canada. Paper No.02-620.

Béline, F., Daumer, M.L., Guiziou, F. 2004. Biological aerobic treatment of pig slurry in France: nutrients removal efficiency and separation performances. Transactions of the ASAE, 47, 3, 857-864.

Béline, F., Daumer, M.L., Guiziou, F. 2003. Traitement biologique aérobie du lisier de porcs: performances des systèmes de séparation de phases et caractéristiques des co-produits. Ingénieries-EAT, $34,25-33$.

Béline, F., Martinez, J., Chadwick, D., Guiziou, F., Coste, C.-M.. 1999. Factors affecting nitrogen transformations and related nitrous oxide emissions from aerobically treated piggery slurry. Journal of Agricultural Engineering Research, 73, 3, 235-243.

Boiran B.; Couton Y.; Germon J.C. 1996. Nitrification and denitrification of liquid lagoon piggerey waste in a biofilm infiltration-percolation aerated system (BIPAS) reactor. Bioresource Technology, 55, 63-77. Bouwman A.F. \& Booij H., 1998. Global use and trade of feedstuffs and consequences for the nitrogen cycle. Nutrient Cycling in Agroecosystems, 52, 261-267.

Burton, C.H. Sneath, R.W.; Misselbrook, T. H.; Pain, B. F. (1998) The effect of farmscale aerobic treatment of piggery slurry on odour concentration, intensity and offensiveness. Journal of Agricultural Engineering Research 71 203-211 
Burton, C.H., Martinez, J. 2008. Contrasting the management of livestock manures in Europe with that practised in Asia: what lessons can be learnt? Outlook on Agriculture 37, (3), 195-201.

Burton, C.H.; Turner, C. (editors), 2003. Manure management - treatment strategies for sustainable agriculture; second edition Silsoe Research Institute, Wrest Park, Silsoe, Bedford, UK. 490 pages. Choudhary, M., Bailey, L.D., Grant, C.A. 1996. Review of the use of swine manure in crop production : effects on yield and compositiona and on soil and water quality. Waste Management and Research 14, 581-595.

Copeland, C. 2006. Air quality issues and animal agriculture: a primer. CRS Report for Congress, RL32948. Congressional Research Service.

Delgado, C., Rosegrant, M., Steinfeld, H., Ehui, S., Courbois, C. 1999. Livestock to 2020. The next food revolution. Washington, International food Policy Research Institute, Food and Agriculture Organisation of the United Nations, International Livestock Research Institute.

Duxbury, J.M. 1994. The significance of agricultural sources of greenhouse gases. Fertiliser Research Vol 38, pp 151-163.

ECETOC (European Centre for Ecotoxicology and Toxicology of Chemicals), 1994. Ammonia emission to air in Western Europe. Tech. Rep. N 62. ECETOC, Brussels, Belgium.

EDGAR 2006 EDGAR 3.2 Fast Track 2000. Data service run by the Netherlands Environmental Assessment Agency. Website : http:/www.mnp.nl/edgar/model/v32ft2000edgar/ EEC/91/676, O.J. NL 375, 31.12.1991.p1. Protection of waters against pollution caused by nitrates from agricultural sources.

Ehui, S., Li-Pun, H., Mares, V., Shapiro, B. 1998. The role of livestock in food security and environmental protection. Outlook on Agriculture, vol 27, N², 81-87

FAO. Livestock's long shadow. Environmental issues and options. Rome : Food and Agriculture Organisation, 2006: 414.

Faye, B. \& Alary, V. 2001. Les enjeux des productions animales dans les pays du Sud. INRA Productions Animales, 14 (1), 3-13.

Gerber, P., Chilonda, P., Franceschini, G., Menzi, H. 2005. Geographical determinants and environmental implications of livestock production intensification in Asia. Bioresource Technology, Vol 96, Issue 2, pp 263-276. 
Mallard, P. 2006. Regulations on the environment. In: Livestock production and society (Editors, R Geers and F Madec). Wageningen Academic Publishers, The Netherlands. 307 pages.

Martinez, J. 1997. Solepur: a soil treatment process for pig slurry with subsequent denitrification of drainage water. Journal of Agricultural Engineering Research. 66, 51-62.

Martinez, J., Le Bozec, G., 2000. Déjections porcines et problèmes environnementaux en Europe. Cahiers Agriculture, 9, 181-190.

Martinez, J.; Burton, C.H.; Sneath, R.W.; Farrent, J.W. (1995) A study of the potential contribution of sedimentation to aerobic treatment processes for pig slurry. Journal of Agricultural Engineering Research 1995, 61: 87-96.

Martinez, J., Guiziou, F., Peu, P., Gueutier, V. 2003. Influence of treatment techniques for pig slurry on methane emissions during subsequent storage. Biosystems Engineering, 85 (3), 347-354.

McMichael, A.J., Powles, J.W., Butler, C.D., Uauy, R. 2007. Food, livestock production, energy, climate change, and health. Lancet 370, 1253-63. (published on line:www.thelancet.com).

Melse, R.W., Verdoes, N. 2005. Evaluation of four farm-scale systems for the treatment of liquid pig manure. Biosystems Engineering, 92 (1), 47-57.

Nicholson F.A., Groves S.J. and Chambers B.J. (2005). Pathogen survival during livestock manure storage and following land application. Bioresource Technology. 96 (2) : 135-143

Nicholson, R.J., Webb, J., Moore, A. 2002. A review of the environmental effects of different livestock manure storage systems, and a suggested procedure for assigning environmental ratings. Biosystems Engineering. 81 (4), 363-377.

OCDE 2001. Environmental indicators for agriculture. Methods and results. Vol.3. Paris, France.

Olivier, J.G.J., Bouwman, A.F., Van der Hoek, K.W., Berdowski, J.J.M. 1998. Global air emission inventories for anthropogenic sources of $\mathrm{NO}_{\mathrm{x}}, \mathrm{NH}_{3}$ and $\mathrm{N}_{2} \mathrm{O}$ in 1990. Environmental Pollution, 102, $\mathrm{S} 1$, $135-148$.

Pain, B.F. 1999. Gaseous pollutants from organic waste use in agriculture. In Proceedings of the $8^{\text {th }}$ International Conference of the FAO-Network on Recycling Agric., Municipal and Industrial Residues in Agriculture (Ramiran 98). J.Martinez \& M.N. Maudet (eds), Rennes, France. 26-29 May 1998. CemagrefFAO editions, pp 
Pourcher, A-M., Marti, R., Thorigné, A., Jégou, B., Dabert, P. 2007. Effect of anaerobic storage and aerobic digestion on the micro-organisms of in pig manure: cultural and molecular approaches. XIII Congrès International de l'International Society for Animal Hygiene, Tartu (Estonie), 17 au 21 juin 2007. p 926-932.

Ritter, W.F.; Eastburn, R.P. 1978.Treatment of dairy cattle wastes by a barriered landscape wastewater renovation system. Journal Water Pollution Control Federation. 50 (1), 144-150.

Schröder, J. 2005. Revisiting the agronomic benefits of manure : a correct assessment and exploitation of its fertilizer value spares the environment. Bioresource Technology, 96, 253-261.

Seedorf, J., Hartung, J. 1999. Survey of ammonia concentrations in livestock buildings. Journal of Agricultural Science, Cambridge, 133, 433-437

Szögi, A.A.; Humenik, F.J.; Rice, J.M.; Hunt, P. 1997. Swine wastewater treatment by media filtration. Journal of Environmental Science and Health, B32(5), 831-843.

Takai, H.; Pederson, S. 2002. Livestock related fine dust - composition, structure and flows. Landbauforschung Volkenrode 235, 139-144.

Turner, C.; Burton, C.H. 1997 The inactivation of viruses in pig slurries: a review. Bioresource Technology. 61. 9-20

Van der Peet-Schwering, C.M.C., Aarnink, A.J.A., Rom, H.B., Dourmad, J.Y. 1999. Ammonia emissions from pig houses in the Netherlands, Denmark and France. Livestock Production Science. 58, 265-269 Voermans, J.A.M., Verdoes, N., Den Hartog, L.A. 1994. Environmental impact of pig farming. Pig News and Information. $15(2), 51 \mathrm{~N}-54 \mathrm{~N}$.

Windhorst, H-W. 2006; Regional patterns of livestock and poultry production in Europe. In: Livestock production and society (Editors, R Geers and F Madec). Wageningen Academic Publishers, The Netherlands. 307 pages. 
1

2

Table 1. Projected trends in production of various livestock products, 1993-2020.

\begin{tabular}{lccr}
\hline Region/product & $\begin{array}{c}\text { Projected annual growth of } \\
\text { total production }\end{array}$ & \multicolumn{2}{c}{ Total production } \\
\cline { 2 - 4 } & $1993-2020$ & 1993 & (million metric tons) \\
\cline { 2 - 4 } & $(\%)$ & 35 & 38 \\
\hline Developed world & 0.6 & 37 & 41 \\
Beef & 0.4 & 27 & 36 \\
Pork & 1.2 & 100 & 121 \\
Poultry & 0.7 & 348 & 371 \\
Meat & 0.4 & & 44 \\
Milk & & 22 & 81 \\
Developing world & 2.6 & 39 & 47 \\
Beef & 2.7 & 21 & 183 \\
Pork & 3.0 & 88 & 401 \\
Poultry & 2.7 & 164 & \\
Meat & 3.2 & & \\
Milk & & & \\
\hline
\end{tabular}

From Delgado et al. (1999) 
Table 2. Global nitrogen intake for nutrition of humans and animals.

\begin{tabular}{lc}
\hline Category & $\begin{array}{c}\text { Consumption of N } \\
\text { (million tons) }\end{array}$ \\
\hline Humans (inhabitants 5.6 billions) & 23.7 \\
- via vegetable products & 15.2 \\
- via animal products & 8.5 \\
Pigs and poultry & 21.6 \\
Cattle, sheep, etc. & 92.8 \\
- via feedstuffs & 9.8 \\
- via grassland products & 83.0 \\
\hline
\end{tabular}

From Bouwman \& Booij, 1998 
1

Table 3. Indicative values for the $\mathrm{N}$ transfer efficiency at the farm and underlying levels.

\begin{tabular}{lc}
\hline Step(s) in the N cycle & $\begin{array}{c}\text { Transfer efficiency } \\
(\%)\end{array}$ \\
\hline From feed to milk and meat & $20-40$ \\
From manure to soil & $50-90$ \\
From soil to crop & $40-80$ \\
From crop to feed & $80-90$ \\
Whole dairy farm & $10-40$ \\
Whole arable farm & $40-80$ \\
\hline
\end{tabular}


1

Table 4. Annual global methane and nitrous oxide emissions.

\begin{tabular}{lcc}
\hline & $\begin{array}{c}\text { Methane } \\
\text { (Million tons) }\end{array}$ & $\begin{array}{c}\text { Nitrous oxide } \\
\text { (Million tons) }\end{array}$ \\
\hline Waste handling & 56 & 0.27 \\
Biomass burning & 7 & 0.39 \\
Agriculture & 134 & 9.65 \\
Industrial processes & 1 & 0.74 \\
Biofuel & 14 & 0.18 \\
Fossil Fuel & 91 & 0.29 \\
\hline Total & 302 & 11.52
\end{tabular}


Table 5. Greenhouse-gas emissions per year from livestock

\begin{tabular}{lccc}
\hline & $\begin{array}{c}\text { Carbon } \\
\text { dioxide } \\
\text { (global, 2002) }\end{array}$ & $\begin{array}{c}\text { Methane } \\
\text { enteric } \\
\text { (global, 2004) }\end{array}$ & $\begin{array}{c}\text { Methane } \\
\text { manure } \\
\text { (global, 2004) }\end{array}$ \\
\hline Cattle & 1906 & $75^{* \dagger}$ & $8 \ddagger$ \\
Small ruminants (sheep and goats) & 514 & 9 & 0.3 \\
Pigs & 590 & 1 & 8 \\
Camels & 18 & - & - \\
Horses & 71 & - & - \\
Poultry & 61 & - & 18 \\
\hline Total & 3161 & 86 & - \\
\hline Data are million tonnes of gas. * Dairy cattle account for a quarter of enteric methane emissions from \\
cattle. † Buffaloes contribute 9 million tons. $\neq$ Buffaloes contribute 0.3 million tons. \\
From McMichael et al., (2007)
\end{tabular}


1

2

Table 6. Airborne dust, bacteria, fungi and endotoxin concentration in livestock buildings.

\begin{tabular}{lccc}
\hline & Cattle buildings & Pig buildings & Poultry buildings \\
\hline Inhalable dust $\left(\mathrm{mg} / \mathrm{m}^{3}\right)$ & 0.4 & 2.2 & 3.6 \\
Reparable dust $\left(\mathrm{mg} / \mathrm{m}^{3}\right)$ & 0.1 & 0.2 & 0.4 \\
Inhalable endotoxin $\left(\mathrm{EU} / \mathrm{m}^{3}\right)$ & 140.0 & 670.0 & 2000.0 \\
Respirable endotoxin $\left(\mathrm{EU} / \mathrm{m}^{3}\right)$ & 10.0 & 70.0 & 210.0 \\
Bacteria $\left(\log \mathrm{cfu}^{3} / \mathrm{m}^{3}\right)$ & 4.3 & 5.1 & 6.4 \\
Fungi $\left(\log \mathrm{cfu} / \mathrm{m}^{3}\right)$ & 3.8 & 3.7 & 4.0 \\
\hline
\end{tabular}

From Takai and Petersen (2002) 
Table 7. Estimation of annual emissions of specific gases for a conventional system and for 3 options of biological treatment.

\begin{tabular}{lccccc}
\hline & $\begin{array}{c}\mathrm{NH}_{3} \\
(\mathrm{~kg} \mathrm{~N})\end{array}$ & $\begin{array}{c}\mathrm{N}_{2} \mathrm{O} \\
(\mathrm{kg} \mathrm{N})\end{array}$ & $\begin{array}{c}\mathrm{CH}_{4} \\
\text { (tons C) }\end{array}$ & $\begin{array}{c}\mathrm{CO}_{2} \\
\text { (tons C) }\end{array}$ & $\begin{array}{c}\mathrm{CH}_{4}+\mathrm{N}_{2} \mathrm{O} \\
\text { (tonsCO }\end{array}$ \\
\hline Traditional system & 824 & 0 & 14.7 & 11.5 & 413 \\
Treatment option 1 & 265 & 139 & 4.2 & 7.6 & 185 \\
Treatment option 2 & 392 & 133 & 4.3 & 12.6 & 186 \\
Treatment option 3 & 577 & 121 & 4.7 & 16.3 & 190 \\
\hline
\end{tabular}

Treatment option 1 : storage + biological treatment + decanting

Treatment option $2:$ storage + compacting screw + biological treatment + decanting

Treatment option 3 : storage + decanter centrifuge + biological treatment + decanting From Loyon et al. (2007) 
Table 8. Concentrations of bacteria (per gram of wet weight) and occurrence of L. monocytogenes in raw manures and treatment by-products from 17 piggeries

\begin{tabular}{|c|c|c|c|c|c|c|}
\hline Manure treatment & $\begin{array}{l}\text { Type of product } \\
\text { (number of } \\
\text { samples) }\end{array}$ & E. coli & Enterococci & C. perfringens & Salmonella & 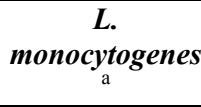 \\
\hline & & \multicolumn{5}{|c|}{ Mean (min- max) } \\
\hline $\begin{array}{c}\text { One month } \\
\text { anaerobic storage }\end{array}$ & Raw manure (12) & $\begin{array}{c}\mathbf{2 ~ 1 \mathbf { 1 0 } ^ { 4 }} \\
\left(0.02-5 \cdot 10^{4}\right)\end{array}$ & $\begin{array}{c}\mathbf{7 1 \mathbf { 1 0 } ^ { 4 }} \\
\left(0.2 \text { to } 3110^{4}\right)\end{array}$ & $\begin{array}{c}9 \mathbf{9 0}^{3} \\
\left(0.08 \text { to } 7210^{3}\right)\end{array}$ & $\begin{array}{c}\mathbf{0 . 1} \\
(\mathrm{ND} \text { to } 0.9)\end{array}$ & $50 \%$ \\
\hline $\begin{array}{c}4 \text { to } 6 \text { months } \\
\text { anaerobic storage }\end{array}$ & Raw manure (5) & $\begin{array}{c}\mathbf{5} \mathbf{1 0}^{\mathbf{4}} \\
\left(0.2 \text { to } 10.10^{4}\right)\end{array}$ & $\begin{array}{c}\mathbf{4} \mathbf{1 0}^{\mathbf{4}} \\
\left(0.1 \text { to } 1410^{4}\right)\end{array}$ & $\begin{array}{c}1 \mathbf{1 0}^{\mathbf{3}} \\
\left(0.5 \text { to } 410^{3}\right)\end{array}$ & $\begin{array}{c}\mathbf{2} \\
\text { (ND to } 11)\end{array}$ & $0 \% \%^{\mathrm{e}}$ \\
\hline $\begin{array}{c}\text { Raw manure physical } \\
\text { separation }\end{array}$ & $\begin{array}{c}3 \text { months stored raw } \\
\text { manure separated } \\
\text { solid (4) }\end{array}$ & $\begin{array}{c}12 \\
\text { (ND to } 38)\end{array}$ & $\underset{\left(<10^{-3}\right)}{\text { ND }}$ & $\begin{array}{c}\mathbf{6} \\
\text { (ND to } 19)\end{array}$ & $\underset{\left(<410^{-4}\right)}{\text { ND }}$ & $0 \%{ }^{\mathrm{e}}$ \\
\hline $\begin{array}{c}\text { Aerobic digestion } \\
\text { followed by anaerobic } \\
\text { storage }\end{array}$ & $\begin{array}{l}\text { Sludge from treated } \\
\text { manure }(10)\end{array}$ & $\begin{array}{c}\mathbf{5} \mathbf{1 0}^{\mathbf{2}} \\
\left(0.4 \text { to } 10.10^{2}\right)\end{array}$ & $\begin{array}{c}\mathbf{4} \mathbf{1 0}^{\mathbf{3}} \\
\left(0.1 \text { to } 610^{3}\right)\end{array}$ & $\begin{array}{c}\mathbf{8 1 0}^{\mathbf{3}} \\
\left(0.1 \text { to } 5210^{3}\right)\end{array}$ & $\begin{array}{c}\mathbf{6} \mathbf{1 0}^{-\mathbf{3}} \\
(\mathrm{ND} \text { to } 0.04)\end{array}$ & $20 \%$ \\
\hline $\begin{array}{l}\text { Aerobic digestion } \\
\text { followed by sludge } \\
\text { separation and pond }\end{array}$ & $\begin{array}{c}6 \text { months stored } \\
\text { liquid from treated } \\
\text { manure }(8)\end{array}$ & $\begin{array}{c}\mathbf{4} \\
(1 \text { to } 14)\end{array}$ & $\begin{array}{c}77 \\
\text { (ND to } 453 \text { ) }\end{array}$ & $\begin{array}{c}\mathbf{4 0} \\
(\mathrm{ND} \text { to } 210)\end{array}$ & $\underset{\left(<410^{-4}\right)}{\text { ND }}$ & $0 \%{ }^{\mathrm{e}}$ \\
\hline
\end{tabular}

${ }^{a}$ frequency of detection of Listeria monocytogenes (\%); ND, not detected.

From Pourcher et al (2007) 
Legends of figures

Figure 1. Estimates of cattle and pig numbers by continents in 2004 (from Windhorst, 2006, Source FAO - Database)

Figure 2. Main pathways of sources and sinks of greenhouse gases associated with agriculture (from OECD, 2001)

Fig. 3: Cumulative methane emissions during storage for an experiment comparing a control raw slurry $(\bigcirc)$ and the effect of addition of three commercial additives: NX23 ( $\nabla)$ Stalosan $(\boldsymbol{\square})$, Biosuper $(\diamond)$; standard deviation is plotted for each measuring point (from Martinez et al., 2003)

Fig. 4 Cumulative methane emissions during storage for an experiment comparing a control raw slurry $(\mathbf{O})$, a separated slurry $(\nabla)$ and a slurry previously aerated (ם) (fine bubbles system); standard deviation is plotted for each measuring point (from Martinez et al. 2003)

Figure 5. Average emission of $\mathrm{NH}_{3}, \mathrm{CH}_{4}, \mathrm{~N}_{2} \mathrm{O}$, greenhouse gases (GHG; sum of $\mathrm{CH}_{4}$ and $\mathrm{N}_{2} \mathrm{O}$ ), and odour from four treatment systems for liquid pig manure; emissions are expressed per tonne of manure input; for system 4, only odour and $\mathrm{NH}_{3}$ emissions were measured: , system 1, straw filtration;

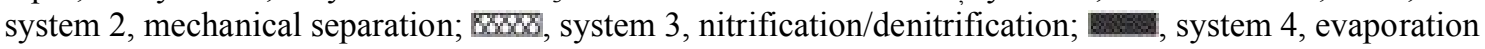
(from Melse \& Verdoes, 2005) 
1

2

3

4

5

6

7

8

9

10

11

12

13

14

15

16

17

18

19

20

21

22

23

24

25

26

27

28

29

30

31

32

33

34

35

36

37

38

39

40

41

42

43

44

45

46

47

48

49

50

51

52

53

54

55

56

57

58

59

60

61

62

63

64

65

\section{Millions of head}

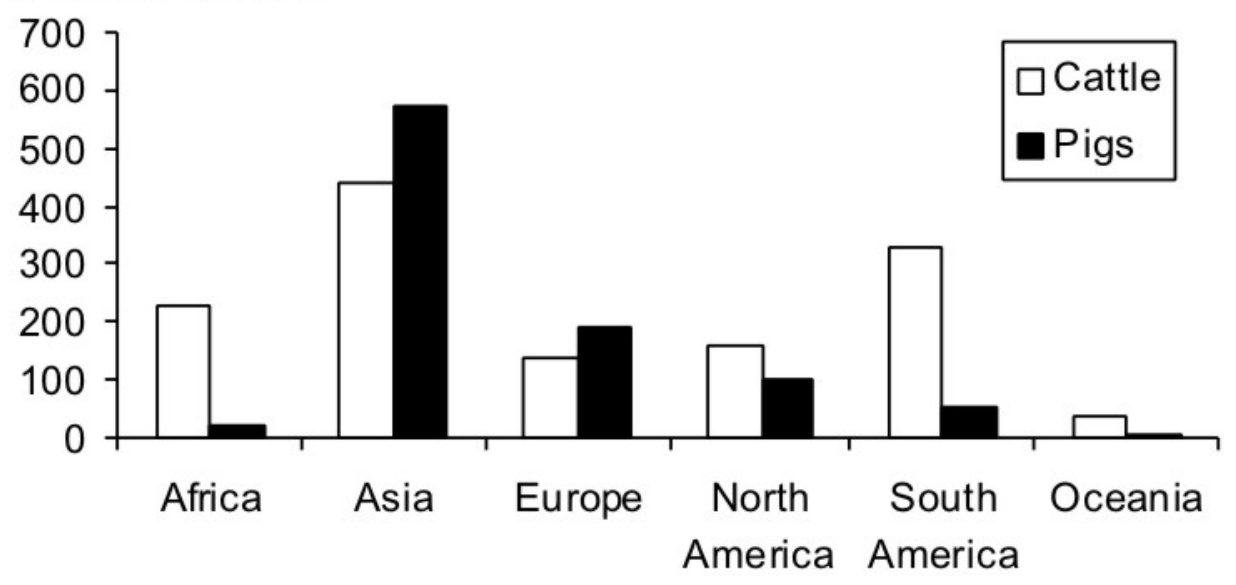

Figure 1 


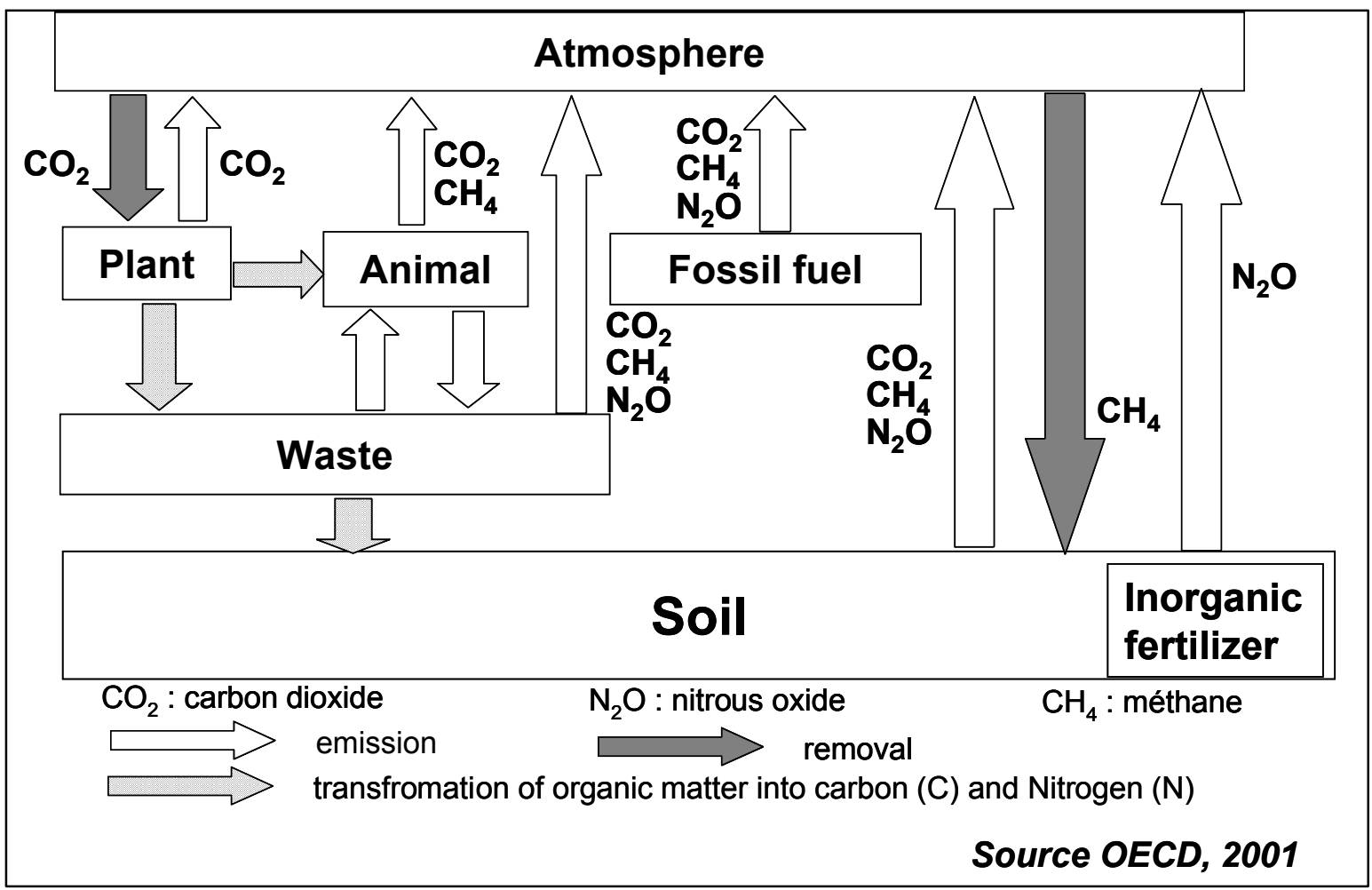

Figure 2 
1

2

3

4

5

6

8

9

10

11

12

13

14

15

16

17

18

19

20

21

22

23

24

25

26

27

28

29

30

31

32

33

34

35

36

37

38

39

40

41

42

43

44

45

46

47

48

49

50

51

52

53

54

55

56

57

58

59

60

61

62

63

64

65

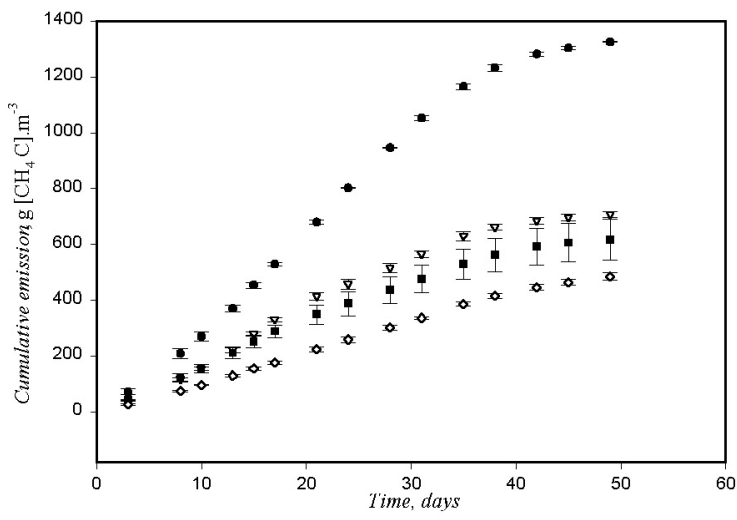

Figure 3 
1

2

3

4

6

7

8

9
10

11

12

13

14

15

16

17

18

19

20

21

22

23

24

25

26

27

28

29

30

31

32

33

34

35

36

37

38

39

40

41

42

43

44

45

46

47

48

49

50

51

52

53

54

55

56

57

58

59

60

61

62

63

64

65

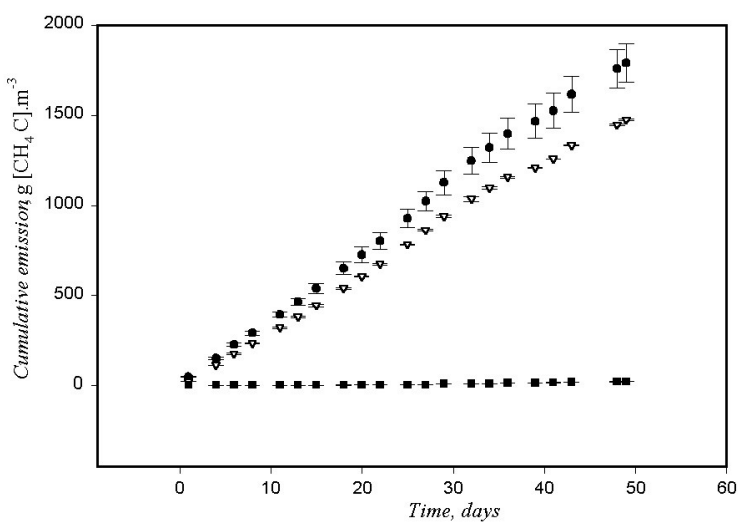

Figure 4 


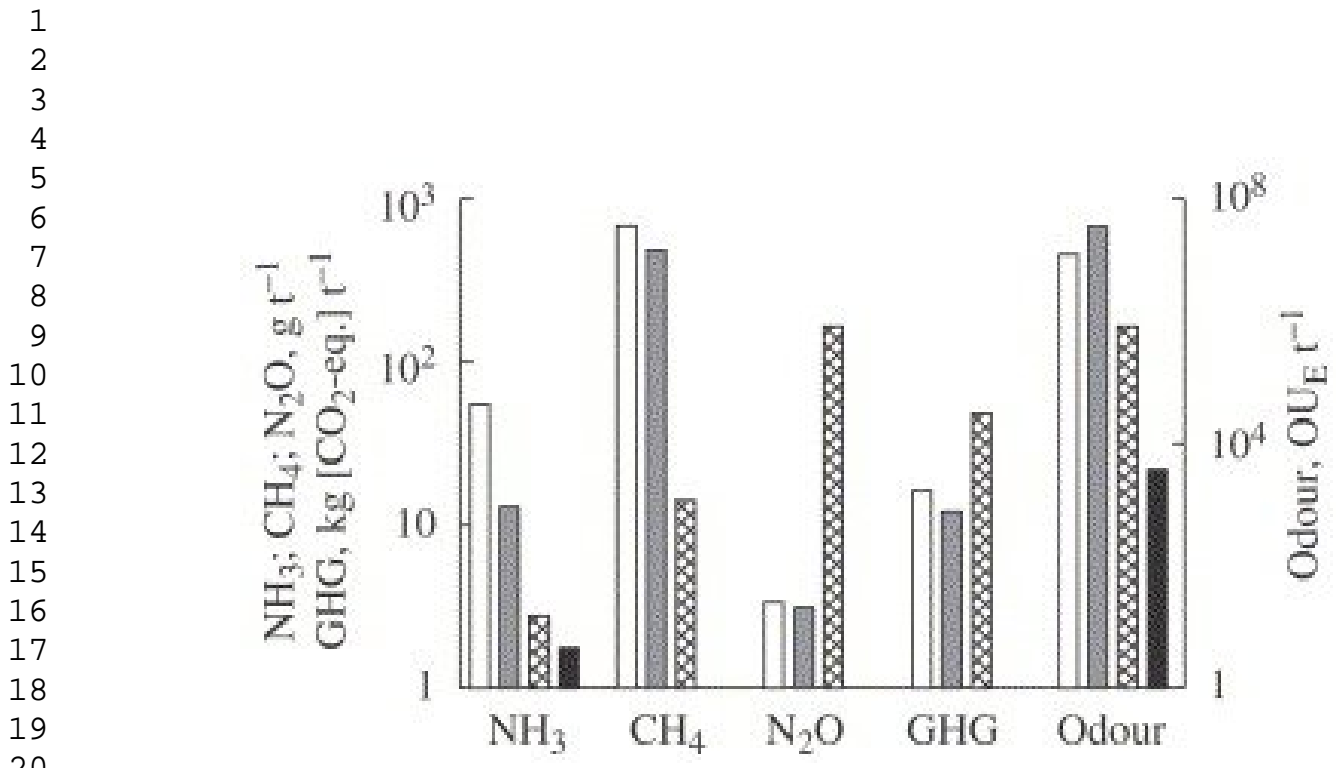

Figure 5 